Check for updates

Cite this: RSC Adv., 2018, 8, 22303

\title{
Protective effects of thornback ray muscle protein hydrolysate against dyslipidemia, oxidative stress and reduced fertility induced by high cholesterol diet in adult male rats
}

\author{
Imen Lassoued, (D) *a Mayassa Mezghani, ${ }^{a}$ Mourad Jridi, ${ }^{a}$ Fatma Rahmouni, \\ Kamel Jamoussi, ${ }^{\mathrm{c}}$ Tarek Rebai, ${ }^{\mathrm{b}}$ Abdelfattah El Feki, ${ }^{\mathrm{d}}$ Moncef Nasri ${ }^{\mathrm{a}}$ \\ and Ahmed Barkia ${ }^{a}$
}

Enzymatic thornback ray (Raja clavata) muscle hydrolysates have been shown to have antioxidant and antihypertensive activities in vitro. The Neutrase hydrolysate exhibited the highest activities, so it was investigated along with the undigested muscle to test their hypolipidemic, antioxidative and fertility effects in rats fed with a high-cholesterol diet (HCD). Animals were allocated into four groups of 5 rats each: a normal diet group (control), a HCD group, and two groups of HCD with a daily dose of undigested muscle (Und) or the hydrolysate $(\mathrm{MH})$ at $0.7 \mathrm{~g} \mathrm{~kg}^{-1}$ of body weight. All animals received their respective treatments daily for 1 month. After the treatment period, serum lipid profiles, the activities of alanine aminotransferase and aspartate aminotransferase, the level of malonaldehyde, the activities of antioxidant enzymes (catalase and glutathione peroxidase) in the liver and sperm fertility parameters (in the epididymis and testis) were determined. Compared with those fed a standard diet, HCD induced dyslipidemia and oxidative stress, and decreased numerous reproductive parameters (mobility, count and viability). Interestingly, supplementing the HCD with thornback ray proteins attenuated all these anomalies, especially in the case where they were hydrolysed. These observations suggested that these proteins might contain bioactive peptides that possess hypocholesterolemic and antioxidant activities that ameliorate sperm damage.

Received 22nd January 2018

Accepted 3rd June 2018

DOI: $10.1039 / c 8 r a 00657 a$

rsc.li/rsc-advances evidence. For example, oral administration of a number of traditional antioxidant and anti-hypercholesterolemic agents (statins, ezetimibe...) has been shown to be effective against the reduced fertility which characterizes the hypercholesterolemic rat. $^{4}$

Habitually, hypolipemic strategy specially includes a suitable life-style (diet, activity...) and use of synthetic lipid-lowering agents. Today, undesirable effects have been attributed to these agents that have become less accepted by the general public and their real interest in health is debated by professionals. In recent years, an effort has been made to develop other alternative products. An important part of this effort was reserved to the use of functional foods and nutraceuticals to treat and manage high cholesterol levels. ${ }^{5}$ These functional foods include whole and purified food proteins, their enzymatic hydrolysates, and constituent peptides, which have been investigated as potential cholesterol and lipid lowering dietary agents in animals and humans. Depending on their sources, structural properties and the presence of other bioactive compounds, these food proteins exhibit hypolipidemic properties through various mechanisms as shown in vivo and on cultured cells. ${ }^{6}$
${ }^{a}$ Laboratory of Enzyme Engineering and Microbiology, University of Sfax, National Engineering School of Sfax, B.P. 1173-3038 Sfax, Tunisia. E-mail: lassouedimen@ yahoo.fr; Fax: +216-74-275-595; Tel: +216-74-274-408

${ }^{b}$ Histology-Embryology Laboratory, Sfax Faculty of Medicine, Sfax, Tunisia ${ }^{c}$ Clinical Chemistry Laboratory, Hedi Chaker University Hospital, Sfax, Tunisia ${ }^{d}$ Animal Ecophysiology Laboratory, Sciences Faculty of Sfax, University of Sfax, Tunisia

\footnotetext{
(a)
}

Cholesterol is a lipid constituent of animals. It has a membrane and a main role as a precursor for the biosynthesis of steroid hormones, bile acids, and vitamin D. However, high cholesterol plasma concentration promotes the development of many diseases such as cardiovascular diseases and degeneration of the nervous system. Also, its negative impact on reproductive fitness is becoming recognized. These pathologies may attributable to unfavorable lipoprotein profiles and oxida of cellular and plasma cholesterol levels can have a significant act on the prevention of infertility in addition to its tional beneficial effect in cardiovascular diseases. This approach has been validated by many pieces of experimental 
In this field, marine proteins appear to be a choice candidate because of their large variability which may allow the production of products with particular properties, and their availability in large quantities at low prices that may allow the obtaining of inexpensive products. Effectively, several researchers groups, have been able to generate various biological activities from different marine proteins in vitro ${ }^{7-9}$ and in vivo. ${ }^{\mathbf{1 0 - 1 2}}$

Thornback ray (Raja clavata) is a species of low market value which is commonly caught in the Mediterranean including in Tunisian littoral. In previous studies, we have produced different thornback ray proteins hydrolysates by the use of different proteases, and we proved their bioactivity. In particular, the hydrolysate obtained by Neutrase showed a strong in vitro antioxidant activity. ${ }^{13}$ In the present study we investigated the effect of this hydrolysate and the undigested muscle on plasma lipids profile and antioxidant status in high-cholesteroldiet fed rats. Also, the rat fertility was examined in function of diet.

\section{Materials and methods}

\subsection{Materials}

Male Wistar rats were purchased from the breeding center of the Central Pharmacy of Tunis (Tunisia). Fresh thornback rays (R. clavata) were obtained from the fish market of Sfax city, Tunisia. The samples were packaged in polyethylene bags, placed in ice and transported to the laboratory within $30 \mathrm{~min}$ and then stored at $-80{ }^{\circ} \mathrm{C}$ until use for hydrolysis. Neutrase ${ }^{\circledR}$ 0.5L metallo-protease from Bacillus amyloliquefaciens and Alcalase ${ }^{\circledR}$ 2.4L serine-protease from Bacillus licheniformis were supplied by Novozymes ${ }^{\circledR}$ (Bagsvaerd, Denmark). Enzyme preparation from Bacillus subtilis A26 and crude alkaline protease extract from $R$. clavata were prepared according to Agrebi et al. ${ }^{\mathbf{1 4}}$ and Lassoued et al.,$^{15}$ respectively.

The composition of the medium used for the production of proteases by B. subtilis A26 was as follows: $40 \mathrm{~g} \mathrm{~L}^{-1}$ hulled grain of wheat, $3.53 \mathrm{~g} \mathrm{~L}^{-1}$ casein peptone, $4 \mathrm{~g} \mathrm{~L}^{-1} \mathrm{CaCl}_{2}, 4 \mathrm{~g} \mathrm{~L}^{-1} \mathrm{NaCl}$, pH 8.0, temperature $37^{\circ} \mathrm{C}$, and speed of agitation $200 \mathrm{rpm}$. After $24 \mathrm{~h}$ of incubation, the culture medium was centrifuged at $8000 \mathrm{~g}$ for $15 \mathrm{~min}$ at $4{ }^{\circ} \mathrm{C}$ and the cell-free supernatant was used for estimation of proteolytic activity.

Intestines $(100 \mathrm{~g})$ were homogenized for $3 \mathrm{~min}$ with $100 \mathrm{ml}$ of extraction buffer (10 mM Tris-HCl, pH 8.0) using a Moulinex® R62 homogenizer. The resulting preparation was centrifuged at $8500 \mathrm{~g}$ for $30 \mathrm{~min}$ at $4{ }^{\circ} \mathrm{C}$. The pellet was discarded and supernatant was collected as crude protease extract.

\subsection{Preparation of thornback ray muscle hydrolysate}

Protein hydrolysate of thornback ray muscle by Neutrase, Alcalase, crude enzyme preparation from $B$. subtilis A26 and $R$. clavata was conducted according to Lassoued et al.,.. ${ }^{13} R$. clavata muscle (500 g), in $1000 \mathrm{ml}$ distilled water, was first cooked at $90{ }^{\circ} \mathrm{C}$ for $20 \mathrm{~min}$ to inactivate endogenous enzymes and then minced and homogenized in a Moulinex® blender for about $3 \mathrm{~min}$. The samples were adjusted to optimal $\mathrm{pH}$ and temperature for each enzyme and enzymes were added to the mixture at the same enzyme/substrate ratio $\left(3 \mathrm{U} \mathrm{mg}^{-1}\right)$. During the reaction, the $\mathrm{pH}$ of the mixture was maintained at the desired values by continuous addition of $4 \mathrm{M} \mathrm{NaOH}$ solution using a $\mathrm{pH}$-stat. The reaction was stopped by heating the solutions at $90{ }^{\circ} \mathrm{C}$ for $10 \mathrm{~min}$ to inactivate enzymes. Muscle hydrolysates were then centrifuged at $5000 \mathrm{~g}$ for $20 \mathrm{~min}$ to separate soluble and insoluble fractions. Finally, the soluble fractions referred to as protein hydrolysates, were freeze-dried using a freeze-dryer.

\subsection{Copper-induced lipid oxidation serum}

Venous blood was taken from healthy individuals and serum was separated and immediately frozen. Then, it was stored at $-80{ }^{\circ} \mathrm{C}$. Copper-induced oxidation was conducted according to Schnitzer et al., ${ }^{16}$ with slight modifications. This test was monitored at $37{ }^{\circ} \mathrm{C}$ while continuously recording the absorbance at $245 \mathrm{~nm} . \mathrm{CuSO}_{4}$ (final concentration $100 \mu \mathrm{M}$ ) was added to a solution containing $720 \mu \mathrm{M}$ sodium citrate in phosphatebuffered saline (146 mM NaCl, $3.3 \mathrm{mM} \mathrm{NaH} \mathrm{PO}_{4}, 3.3 \mathrm{mM}$ $\left.\mathrm{Na}_{2} \mathrm{HPO}_{4}, \mathrm{pH}=7.4\right)$ together with the sample $\left(1 \mathrm{mg} \mathrm{ml}{ }^{-1}\right)$ and $120 \mu \mathrm{l}$ serum in a final volume of $3 \mathrm{ml}$. Then, measurements were carried out in quartz cuvettes (optical pathway $1 \mathrm{~cm}$ ). The control was conducted in the same manner, except that distilled water was used instead of sample. This analysis was done as a characterisation of the hydrolysates, to know their antioxidant properties, prior to the in vivo investigation.

\subsection{Ethics statement}

Animal maintenance and experimental procedures were performed in accordance with the Guidelines for Care and Use of Laboratory Animals of Tunis University and approved by the Animal Ethics Committee of National Institute of Health. ${ }^{17}$

\subsection{Animals and diets}

For the purposes of this study, twenty male Wistar rats (200 g) were used in this study. The animals were housed in individual cages in a controlled breeding room (temperature: $22{ }^{\circ} \mathrm{C}$, humidity: $60 \%, 12 \mathrm{~h}$ light-dark cycle) and allowed free access to water and alimentation. After the acclimation period, rats were randomly divided into four groups (5 animals/each): group control, rats were fed basal diet all over the period of the experiment. The characteristic of the standard diet, provided by the Society of Animal Nutrition (SNA), Sfax, Tunisia, is reported in Table 1. Group Chol, rats were fed high cholesterol diet (HCD) (basal diet supplemented with 1\% cholesterol and 0.1\% cholic acid). Group Und and $\mathrm{MH}$ rats were fed a cholesterolenriched diet gavaged daily by $0.7 \mathrm{~g}$ non hydrolyzed or hydrolysed thornback ray muscle per kg of animal body weight (BW), respectively. All animals were received their respective treatments daily for 1 month. Animal's weights were recorded at the start and at the end of the experiment in order to obtain the body weight gain.

\subsection{Blood and tissues collection}

At the end of the experimental period, animals were fasted for 12 hours and then sacrificed under diethyl ether anesthesia. 
Table 1 Composition of basic food (Society of Animal Nutrition (SNA) Sfax, Tunisia). This food consists of corn, soya, and VMC (vitamins Minerals compound) with the following characteristics

Nutritional properties (\%)

Moisture (maximal) 14

Fibers (maximal) 5

Proteins (minimal) 18

Fat (maximal) 3

Ash (maximal) 13.5

Carbohydrate 46.5

Calorific value $\left(\mathrm{kcal} \mathrm{kg}^{-1}\right) 2846$

Amino acids (\%)

Methionine 0.36

Cysteine 0.26

Threonine 0.62

Tryptophan 0.2

Mineral mix $\left(\mathbf{m g ~ k g}^{-1}\right)$
Manganese 80
Iron 48
Copper 18
Zinc 64
Selenium 0.28
Cobalt 0.2
Iodine 2
Vitamin and antioxidant $\left(\mathbf{m g ~} \mathbf{~ k g}^{-1}\right)$
Vitamin A 11.200
Vitamin D3 2800
Vitamin H 25
Antioxidant (BHA-BHT) 100

Blood samples were collected by cardiac puncture in EDTAcontaining tubes and plasma was separated by centrifugation (3000 rpm for $15 \mathrm{~min}$ and at $4{ }^{\circ} \mathrm{C}$ ) and stored at $-80{ }^{\circ} \mathrm{C}$ until use. Liver, kidney, heart and spleen of each rat were carefully removed, weighed and then stored at $-80{ }^{\circ} \mathrm{C}$ until use. Samples of livers tissues were homogenized for $5 \mathrm{~min}$ in TBS buffer (50 mM Tris- $\mathrm{HCl}, 150 \mathrm{mM} \mathrm{NaCl}, \mathrm{pH} 7.4$ ), with a ratio of $(1: 2)$ (w/v), using an Ultra-Turrax homogenizer. Then the homogenates were centrifuged at $11000 \mathrm{~g}$ for $15 \mathrm{~min}$. Other samples were immediately fixed in a $10 \%$ buffered formalin solution for histological studies.

\subsection{Serum laboratory tests}

The complete blood count was carried out automatically using an automated hematology analyzer (URIT-3000, China). Serum alanine aminotransferase (ALT), aspartate aminotransferase (AST), alkaline phosphatase (PAL) activities, and serum and hepatic lipid levels of total triglycerides (TG), total cholesterol (TC), high density lipoprotein-cholesterol (HDL-C), and low density lipoprotein-cholesterol (LDL-C) were measured in frozen aliquots of serum by standardized enzymatic procedures using commercial kits from Biolabo (Maizy, France) on an automatic biochemistry analyzer (Vitalab Flexor E, USA). Very low density lipoprotein-cholesterol (VLDL-C) was calculated for all the groups according to Crook equation: ${ }^{18}$ VLDL-C $=$ TG/2.2. The atherogenic index (AI) was calculated for all the groups according to the Friedewald et al., ${ }^{19}$ equation: $\mathrm{AI}=(\mathrm{LDL}-\mathrm{C}) /$
(HDL-C). Serum urea, uric acid and creatinine levels were estimated using commercially available diagnostic kits (Biomaghreb, Tunisia).

The serum glucose levels were assayed by an enzymatic colorimetric method using a commercially available Glucose Oxidase-PAP kit (Biomaghreb, Tunisia).

The $\alpha$-amylase activity was evaluated according to kinetic method using a commercial kit (BIOLABO, Maizy, France). The coloration intensity is related to the rate of formation of $p$ nitrophenol, which is directly proportional to the $\alpha$-amylase activity. Optical density was measured at $405 \mathrm{~nm}$ and the residual enzymatic activity $\left(\mathrm{U} \mathrm{L}^{-1}\right)$ in each serum was calculated using the following equation:

$$
\begin{aligned}
\alpha \text {-Amylase activity }= & \left(\left(\Delta \mathrm{abs} / \mathrm{min}_{\text {assay }}\right) /\left(\Delta \mathrm{abs} / \min _{\text {calibrator }}\right)\right) \\
& \times \text { calibrator concentration }\left(1 \mathrm{~g} \mathrm{~L}^{-1}\right)
\end{aligned}
$$

\subsection{Lipid peroxidation assay}

Lipid peroxidation in liver tissue homogenates was measured by estimating the malondialdehyde (MDA) level using thiobarbituric acid-reactive substances (TBARS) assay, according to the method of Yagi. ${ }^{20}$ The absorbance was measured at $530 \mathrm{~nm}$ and the results were expressed as the amount of MDA (nmol) per mg of protein.

\subsection{Evaluation of the activities of antioxidant enzymes}

Samples from livers were homogenized as previously described in Section 2.6 and the supernatants were collected in order to evaluate the natural antioxidant defense in the experimental groups. Catalase (CAT) activity was measured according to the Aebi method. ${ }^{21}$

Glutathione peroxidase (GPx) activity was measured as described by Flohe and Gunzler. ${ }^{22}$

\subsection{Spermogram determination}

The quality of the spermatozoa was studied by determination of the spermogram. For this purpose, testes and epididymis were deposited in $2 \mathrm{ml}$ of phosphate buffered saline (PBS) and dilacerated using Stainless-steel (tweezers). The dispersion obtained after $10 \mathrm{~min}$ was used for determine the total sperm account (Malassez cell under optical microscope), the sperm availability (microscopic examination between blade and blade) and the percentage of live spermatozoa (vitality) (eosin-nigrosin test: one drop of medium containing sperm was put on the slide and then this was mixed with a small drop of eosin $(0.5 \%$ in saline). The coverslip was immediately put over the drop and analyzed at an enlargement of $400 \times$. In each slide, 100 sperms were counted and the percentage of sperms was determined). ${ }^{23}$

\subsection{Statistical analysis}

Data are expressed as mean \pm SEM (standard error of mean) and analyzed by one-way ANOVA (analysis of variance), followed by the Tukey test using SPSS package (version 17). $P$-values of less than 0.05 were considered statistically significant. 


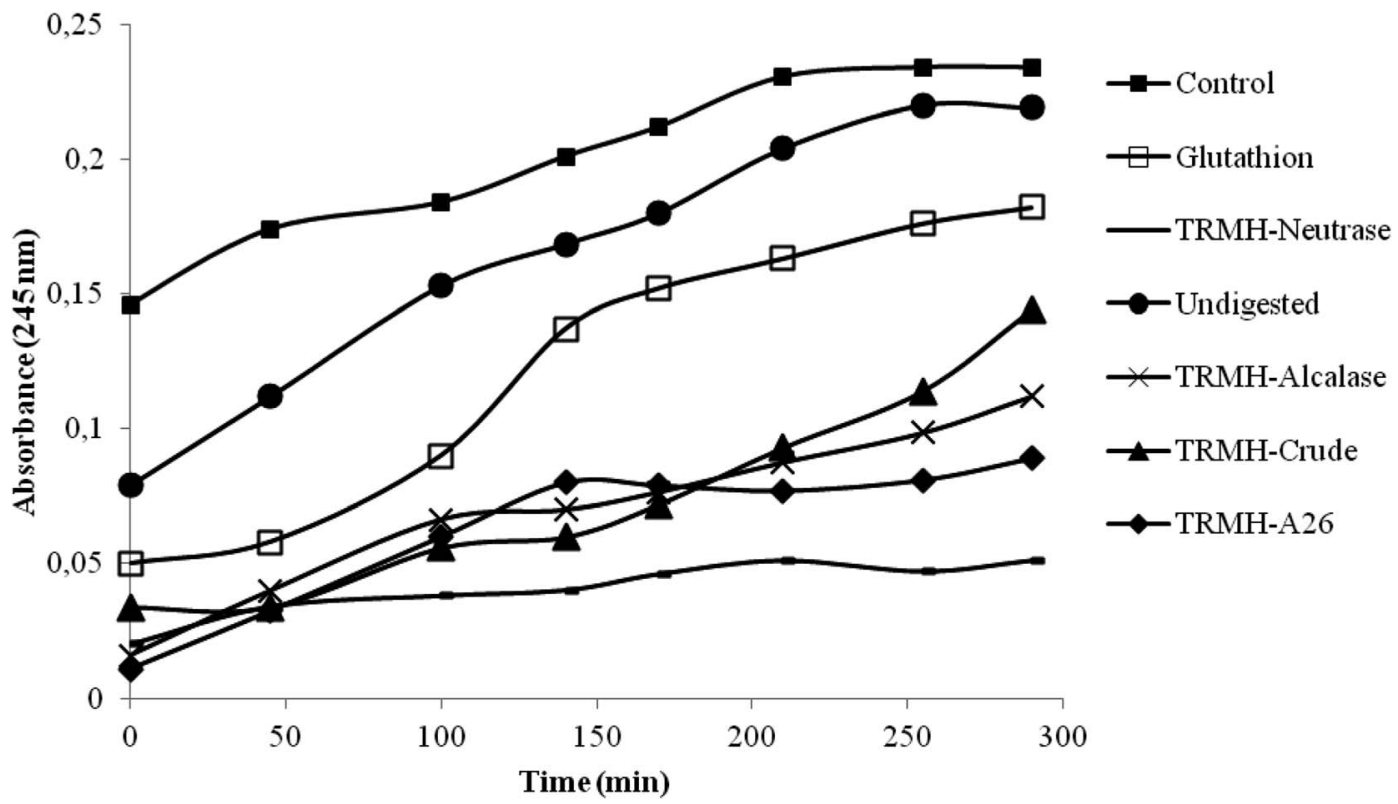

Fig. 1 Representative kinetic profiles of copper-induced oxidation in the serum as monitored spectroscopically at $245 \mathrm{~nm}$. TRMH-Alcalase: thornback ray muscle hydrolysates treated with Alcalase; TRMH-Neutrase: thornback ray muscle hydrolysates treated with Neutrase; TRMHA26: thornback ray muscle hydrolysates treated with enzyme preparation from $B$. subtilis A26; TRMHCrude: thornback ray muscle hydrolysates treated with crude alkaline protease extract from $R$. clavata.

\section{Results and discussion}

\subsection{Copper-induced lipid oxidation in serum}

The inhibition of serum oxidation of the hydrolysates and the glutathion, taken as positive control, is depicted in Fig. 1. The time-dependent increase of absorbance at $245 \mathrm{~nm}$ is mainly due to the formation of conjugated dienic hydroperoxides and 7keto-cholesterol during lipid peroxidation. ${ }^{16}$ The increased defense of serum lipid particles against oxidation was observed with all the hydrolysates and not for the undigested muscle (as compared to the control). The hydrolysates showed a good antioxidant activity better than the glutathion, and the Neutrase hydrolysate possessed the highest activity.

According to a previous study, ${ }^{13}$ Neutrase hydrolysate also showed the best antioxidant activities (DPPH scavenging activity, reducing power assay, $\beta$-carotene bleaching assay and

Table 2 Body weight gain and total feed intake of male Wistar rats fed on experimental $\operatorname{diet}^{a, c}$

\begin{tabular}{lcl}
\hline Group & $\begin{array}{l}\text { Body weight }^{b} \\
\text { gain }^{b}(\mathrm{~g})\end{array}$ & $\begin{array}{l}\text { Total feed intake } \\
\text { (g per group per day) }\end{array}$ \\
\hline Control & $32.4 \pm 12.42$ & $72.69 \pm 4.44$ \\
Chol & $32.8 \pm 9.86$ & $80.27 \pm 1.97^{*}$ \\
Und & $59.4 \pm 14.33$ & $76.73 \pm 2.41^{\#}$ \\
MH & $39.84 \pm 11.24$ & $80.29 \pm 1.91^{*}$
\end{tabular}

${ }^{a}$ Control: normal rats; Chol: rats which were fed a cholesterol-rich diet for 1 month; Und: hypercholesterolemic rats given undigested muscle for 1 month; MH: hypercholesterolemic rats given muscle hydrolysate for 1 month. ${ }^{b}$ Body weight gain $=$ final body weight - initial body weight. ${ }^{c}$ Values differ significantly at $P<0.05$. ${ }^{*} P<0.05$, compared with normal control rats. ${ }^{\#} P<0.05$, compared with hypercholesterolemic rats. the inhibition of supercoiled plasmid DNA scission induced by hydroxyl radicals). This has been assigned to its low hydrolysis degree $(\mathrm{DH}=11 \%)$ which influenced greatly the peptide chain length. ${ }^{13}$ Depending on the specificity of enzymes used during hydrolysis, higher enzymatic cleavage resulted in the formation of shorter chain peptides possessing more hydrophilicity. Those peptides had fewer efficacies in antioxidant activity. ${ }^{13}$ Antioxidant activity was also attributed to the hydrophobic character of the Neutrase hydrolysate. ${ }^{13}$ In fact, Bertinaria et al. ${ }^{24}$ reported the copper ion sequestering ability of carnosine derivatives, and they showed that the most active compounds is the most hydrophobic ones; suggesting that the best activity detected by Neutrase hydrolysate is due essentially to its hydrophobicity.

Due to the highest antioxidant activity of the thornback ray muscle treated with Neutrase, this hydrolysate was chosen to test its hypocholesterolemic effects on rats fed with a highcholesterol diet, at a concentration of $0.7 \mathrm{~g}$ per $\mathrm{kg}$ of animal

Table 3 Relative weight of visceral organs ( $\mathrm{g} / 100 \mathrm{~g}$ of body weight) of male Wistar rats fed on experimental $\operatorname{diet}^{a, b}$

\begin{tabular}{lllll}
\hline Group & Liver & Kidney & Heart & Spleen \\
\hline Control & $2.99 \pm 0.21^{\#}$ & $0.77 \pm 0.02$ & $0.24 \pm 0.02$ & $0.23 \pm 0.01^{\#}$ \\
Chol & $4.06 \pm 0.21^{*}$ & $0.77 \pm 0.01$ & $0.34 \pm 0.03$ & $0.36 \pm 0.02$ \\
Und & $3.79 \pm 0.03$ & $0.81 \pm 0.01$ & $0.35 \pm 0.02$ & $0.23 \pm 0.00^{\#}$ \\
MH & $3.25 \pm 0.19^{\#}$ & $0.82 \pm 0.01$ & $0.36 \pm 0.02$ & $0.26 \pm 0.03^{\#}$
\end{tabular}

${ }^{a}$ Control: normal rats; Chol: rats which were fed a cholesterol-rich diet for 1 month; Und: hypercholesterolemic rats given undigested muscle for 1 month; MH: hypercholesterolemic rats given muscle hydrolysate for 1 month. ${ }^{b}$ Values differ significantly at $P<0.05 .{ }^{*} P<0.05$, compared with normal control rats. ${ }^{\#} P<0.05$, compared with hypercholesterolemic rats. 
Table 4 Hematological parameters of male Wistar rats fed on experimental $\operatorname{diets}^{a}$

\begin{tabular}{|c|c|c|c|c|}
\hline Parameter & Control & Chol & Und & $\mathrm{MH}$ \\
\hline $\operatorname{WBC}\left(10^{3} \mu \mathrm{l}^{-1}\right)$ & $11.20 \pm 0.74$ & $12.92 \pm 1.60$ & $12.2 \pm 0.98$ & $11.73 \pm 1.01$ \\
\hline $\operatorname{RBC}\left(10^{6} \mu \mathrm{l}^{-1}\right)$ & $8.07 \pm 0.27$ & $8.19 \pm 0.16$ & $8.34 \pm 0.17$ & $8.41 \pm 0.07$ \\
\hline Htc (\%) & $41.02 \pm 1.52$ & $42.37 \pm 0.32$ & $42.36 \pm 0.86$ & $42.55 \pm 0.48$ \\
\hline MCV (fL) & $50.78 \pm 0.52$ & $50.70 \pm 0.42$ & $50.82 \pm 0.10$ & $50.80 \pm 0.15$ \\
\hline $\mathrm{MCH}(\mathrm{pg})$ & $16.98 \pm 0.19$ & $16.26 \pm 0.17$ & $16.16 \pm 0.05$ & $16.42 \pm 0.06$ \\
\hline $\operatorname{Lym}\left(10^{3} \mu 1^{-1}\right)$ & $7.33 \pm 0.17$ & $7.58 \pm 0.73$ & $7.58 \pm 0.89$ & $7.30 \pm 0.46$ \\
\hline
\end{tabular}

${ }^{a}$ WBC, White Blood Cells; RBC, Red Blood Cells; Hb, Hemoglobin; Htc, Hematocrit; MCV, Mean Corpuscular Volume; MCH, Mean Corpuscular Hemoglobin; MCHC, Mean Corpuscular Hemoglobin Concentration; PLT, Platelets; Lym, Lymphocytes. Control: normal rats; Chol: rats which were fed a cholesterol-rich diet for 1 month; Und: hypercholesterolemic rats given undigested muscle for 1 month; MH: hypercholesterolemic rats given muscle hydrolysate for 1 month. Statistically significant differences were not found.

body weight. The undigested muscle was also tested at the same concentration.

\subsection{Effects on weight gain and organs weight}

At the baseline, the mean body-weight of the experimental rats was $200 \mathrm{~g}$. There were no significant differences in the bodyweight gain among the different diet groups of male Wistar rats at completion of the experiment (Table 2). The average feed intakes by the male Wistar rats in the different dietary groups over the study period are presented in Table 2 . The addition of muscle hydrolysate to the hypercholesterolemic diet did not affect the food intake which was significantly similar to the cholesterol rich diet group (Table 2), while $\mathrm{MH}$ and Chol groups differed significantly compared to control rats.

The liver/body weight ratio increased in rats fed cholesterol rich diet (Chol) compared with those fed a control diet. The hydrolysate significantly decreased the liver/body weight ratio compared to the Chol group and in this way the ratio is equaled to that from the control group. Similar results were reported by Srih Belguith et al. ${ }^{25}$ in the treatment of hypercholesterolemic rats with levan polysaccharide.

There was no significant difference in the relative weight of the heart and kidney for the four diet groups; and for spleen, the control, Und and $\mathrm{MH}$ groups showed a significant difference compared to Chol group (Table 3).

Table 5 Effect of experimental diets on some hepatic function parameters in different rat groups ${ }^{a, b}$

\begin{tabular}{lllr}
\hline Group & AST $\left(\mathrm{UI} \mathrm{L}^{-1}\right)$ & ALT $\left(\mathrm{UI} \mathrm{L}^{-1}\right)$ & PAL $\left(\mathrm{UI} \mathrm{L}^{-1}\right)$ \\
\hline Control & $134.50 \pm 19.00$ & $37.00 \pm 3.36$ & $74.00 \pm 10.00$ \\
Chol & $190.30 \pm 11.5^{*}$ & $50.00 \pm 7.00^{*}$ & $109.00 \pm 26.00^{*}$ \\
Und & $153.30 \pm 34.60$ & $43.50 \pm 0.70$ & $101.20 \pm 15.32$ \\
MH & $154.10 \pm 10.69$ & $36.50 \pm 2.42^{\#}$ & $93.00 \pm 10.56$
\end{tabular}

${ }^{a}$ Control: normal rats; Chol: rats which were fed a cholesterol-rich diet for 1 month; Und: hypercholesterolemic rats given undigested muscle for 1 month; $\mathrm{MH}$ : hypercholesterolemic rats given muscle hydrolysate for 1 month. ${ }^{b}$ Values differ significantly at $P<0.05$. ${ }^{*} P<0.05$, compared with normal control rats. ${ }^{\#} P<0.05$, compared with hypercholesterolemic rats.

\subsection{Effects on hematological parameters}

The behavior of the different rat groups was normal throughout the experimental period. In order to confirm the normal health condition of the animals, a complete blood check was performed and the results are presented in Table 4 . There were no significant differences in the levels of the measured hematological parameters between control group, Chol group, Und and MH groups $(P>0.05)$ after the experimental period of one month. Therefore, based on the observations after consumption of the experimental diets we conclude that, in case of therapeutic use of this hydrolysate as anticholesteremic agent, detrimental effects on the general health status of rats were not detected. Nasri et al. ${ }^{\mathbf{1 0}}$ reported also that the administration of goby protein hydrolysates, at a concentration of $0.4 \mathrm{~g} \mathrm{~kg}^{-1}$, to high fat and fructose diet fed rats did not affect hematological parameters.

\subsection{Evaluation of some hepatic and kidney functions}

The development of oxidative stress causes cell damage or tissue injuries. Furthermore, the latter caused functional impairment as evidenced by hepatic function tests, such as elevated serum of ALT and PAL activities, which demonstrated the severity of cholesterol, induced hepatic damage. ${ }^{26}$ So, the assessment of the level of AST, ALT and PAL provides a good and simple tool to measure the protective activity of the target drug against the hepatic damage of the target compounds. ${ }^{27}$

The changes of plasma AST, ALT and PAL activities of different groups are shown in Table 5. Compared to the control group, high cholesterol diet (HCD) fed rats showed an increase of ALT, AST and PAL $(P<0.05)$. The consumption of such a regime induces damage to the rat liver due to oxidative stress caused by the excess of cholesterol in the diet. The administration of $R$. clavata proteins to HCD-fed rats allowed the prevention of these deleterious changes. The present data corroborates with previous studies showing an improvement of the hepatic function after administration of fish protein hydrolysates to HCD-fed rats. ${ }^{12,28,29}$

Kidney indices of toxicity of our experimental groups were investigated (Table 6). The mean values of urea, creatinine and 
Table 6 Effect of experimental diets on some kidney function parameters in different rat groups ${ }^{a, b}$

\begin{tabular}{llll}
\hline Group & Urea $\left(\mathrm{mmol} \mathrm{L}^{-1}\right)$ & Creatinine $\left(\mu \mathrm{mol} \mathrm{L}^{-1}\right)$ & Uric acid $(\mu \mathrm{mol} \mathrm{L})$ \\
\hline Control & $5.22 \pm 0.33$ & $18.52 \pm 2.06$ & $45.75 \pm 7.28$ \\
Chol & $6.14 \pm 0.55^{*}$ & $24.76 \pm 0.69^{*}$ & $71.79 \pm 3.91^{*}$ \\
Und & $4.94 \pm 0.02$ & $20.28 \pm 1.62$ & $62.14 \pm 15.82$ \\
MH & $5.47 \pm 0.99$ & $15.66 \pm 2.37$ & $60.00 \pm 1.26$
\end{tabular}

${ }^{a}$ Control: normal rats; Chol: rats which were fed a cholesterol-rich diet for 1 month; Und: hypercholesterolemic rats given undigested muscle for 1 month; MH: hypercholesterolemic rats given muscle hydrolysate for 1 month. ${ }^{b}$ Values differ significantly at $P<0.05$. ${ }^{*} P<0.05$, compared with normal control rats. ${ }^{\#} P<0.05$, compared with hypercholesterolemic rats.

uric in the rats fed HCD were significantly higher than that of the control group. Hypercholesterolemia is considered a factor that contributes to renal dysfunction. ${ }^{30}$ Interestingly, proteins of thornback ray reversed these changes to near normal values. Such findings were coincided with that found by Ktari et al. ${ }^{28}$ who showed that zebra blenny hydrolysates improved the level of kidney functions.

\subsection{Effect of tested diets on lipid profile}

Plasma cholesterol, triglycerides, HDL-C, LDL-C, VLDL-C levels and atherogenic index (AI) obtained in different experimental rat groups at the end of the experiment are shown in Table 7. After the treatment, TG, TC, LDL-C, VLDL-C concentrations and AI of rats fed a cholesterol-rich diet (Chol) showed a significant increase compared with control group (control). However, a decrease of HDL-C concentration of rats in the Chol group was observed $(P<0.05)$. The supplementation of Chol group with the protein hydrolysate resulted in significantly lowered TC, HDL-C, LDL-C and VLDL-C. Moreover, the treatment of Chol group with undigested muscle or its hydrolysate significantly re-established their HDL-C level $(P<0.05)$. As a consequence, the atherogenic index (AI) was significantly reduced by oral administration of thornback ray proteins comparing to the Chol group.

Atherogenic index is an indicator of the risk of cardiovascular diseases such as arteriosclerosis and angina. ${ }^{31}$ Although few, there are previous reports on the in vivo hypocholesterolemic potentials of fish hydrolysates, which have similar findings to our work. Lassoued et al., ${ }^{12}$ Ben Khaled et al.,${ }^{29}$ reported the reduction of the AI of rats after incorporating Boops boops and Sardinella

Table 7 Effect of experimental diets on plasma lipid profile and atherogenic index (Al) in different rat groups ${ }^{a, b}$

\begin{tabular}{lllll}
\hline Parameter & Control & Chol & Und & MH \\
\hline TG & $0.57 \pm 0.02$ & $0.80 \pm 0.03^{*}$ & $0.65 \pm 0.09$ & $0.52 \pm 0.08^{\#}$ \\
TC & $1.11 \pm 0.11$ & $1.63 \pm 0.05^{*}$ & $1.2 \pm 0.11^{\#}$ & $1.26 \pm 0.08^{\#}$ \\
HDL-C & $0.30 \pm 0.03$ & $0.21 \pm 0.03^{*}$ & $0.27 \pm 0.01^{\#}$ & $0.28 \pm 0.03^{\#}$ \\
LDL-C & $0.58 \pm 0.07$ & $1.34 \pm 0.07^{*}$ & $0.76 \pm 0.03^{\#}$ & $0.69 \pm 0.13^{\#}$ \\
VLDL-C & $0.26 \pm 0.01$ & $0.42 \pm 0.01^{*}$ & $0.29 \pm 0.04^{\#}$ & $0.23 \pm 0.03^{\#}$ \\
AI & $1.93 \pm 0.37$ & $6.38 \pm 0.67^{*}$ & $2.81 \pm 0.01^{* \#}$ & $2.46 \pm 0.01^{\#}$
\end{tabular}

${ }^{a}$ Control: normal rats; Chol: rats which were fed a cholesterol-rich diet for 1 month; Und: hypercholesterolemic rats given undigested muscle for 1 month; $\mathrm{MH}$ : hypercholesterolemic rats given muscle hydrolysate for 1 month. ${ }^{b}$ Values differ significantly at $P<0.05$. ${ }^{*} P<0.05$, compared with normal control rats. ${ }^{\#} P<0.05$, compared with hypercholesterolemic rats. aurita proteins, respectively, into their cholesterol rich diets. Nasri et al., ${ }^{32}$ showed also that a daily administration of fish goby protein hydrolysates in rats fed a high fat and fructose diet, improved lipid profile revealed by a decrease of TC, TG, LDL-c and VLDL-c levels. They indicate that although undigested fish goby protein showed hypolipidemic effect, but it was less efficient than its hydrolysates. The obtained results demonstrate the importance of in vitro protein hydrolysis.

According to a study about the effect of collagen hydrolysates from salmon and trout skins on the lipid profile in rats, Saito et al., ${ }^{11}$ suggested that plasma triglyceride reduction was due to the intake of amino acids and/or low molecular weight peptides derived from fish collagen peptide absorbed from the intestine. Furthermore, they found correlations between plasma triglycerides and total hydroxyproline, glycine, and proline concentrations: the results indicated that the concentration of triglycerides in rat plasma correlated negatively with plasma total hydroxyproline, glycine and proline. Therefore, it is clear that plasma triglyceride reduction owing to fish collagen peptide intake has a close relationship with the concentration of amino acid derived fish collagen peptides. The effect of thornback ray muscle hydrolysed by Neutrase in lowering of lipid levels might be explained by the presence of some potent bioactive peptides, as well as its high content of hydroxyproline, glycine and proline $(24 \%),{ }^{13}$ which can provide beneficial action in rats fed a cholesterol-rich diet.

\subsection{Evaluation of hypoglycemic effects}

Results, shown in Table 8, clearly demonstrated that high cholesterol diet increased significantly $(P<0.05)$ the level of blood glucose when compared to the control group, which proves that high cholesterol diet does induce an hyperglycemic state. It is interesting to note that the oral administration of undigested protein and the hydrolysate restored normal glucose levels, which show their antihyperglycemic potential.

These results are in agreement with studies reporting the hypoglycemic effect of protein hydrolysates from goby fish muscle in high-fat-high-fructose diet fed rats; meanwhile the undigested goby fish did not reestablish the level of blood glucose. ${ }^{10}$ Following a study about the effects of cereal-mix fermented with probiotic on high cholesterol fed rats; Ogunremi et al. ${ }^{31}$ showed that cereal-based functional food positively influenced serum lipid levels but clearly increased the plasma glucose level. In fact, significant increases in the plasma glucose content were recorded with an increasing supplementation of 
Table 8 Effect of experimental diets on some glycemic indexes in different rat groups ${ }^{a, b}$

\begin{tabular}{|c|c|c|c|c|}
\hline Parameter & Control & Chol & Und & $\mathrm{MH}$ \\
\hline
\end{tabular}

the cereal-based functional food. This last clearly increased the plasma glucose level because cereals are important sources of carbohydrates that supply glucose in the blood. So the interest of using proteins as complementary measure to safely and effectively improve health.

A review reported that $\alpha$-amylase plays important role in the adjustment of blood glucose level. Therefore, the inhibition of this enzyme is considered to be a useful alternative in the treatment of diabetes. Indeed, this inhibition may suppress carbohydrate digestion and retard glucose absorption..$^{33}$ So, the blood $\alpha$-amylase activity was also evaluated in the experimental groups, and the results are shown in Table 8. As expected, high cholesterol diet fed rats showed significant increase in the serum $\alpha$-amylase activity when compared to control rats $(P<$ 0.05). Interestingly, the oral administration of undigested muscle and the hydrolysate decreased the $\alpha$-amylase activity. Nasri et al., ${ }^{10}$ reported the decrease of $\alpha$-amylase activity in highfat-high-fructose diet fed rats by the hydrolysates of goby fish; however the undigested muscle was not only found to be unable to decrease this activity, but it led to a further increase.

\subsection{Evaluation of antioxidant status}

3.7.1. Effect of tested diets on MDA levels in hepatic tissue. It has been established that hypercholesterolemia leads to increased production of oxygen free radicals ${ }^{34}$ which exert their cytotoxic effect by causing lipid peroxidation, resulting in the formation of TBARS. The level of MDA, the best known specific TBARS, in the liver is shown in Fig. 2. A significant increase in MDA level was observed in the liver of hyperlipidemic group compared with the control group. Administration of the undigested muscle and especially the hydrolysate to rats fed cholesterol-based diet decreased significantly the level of MDA compared with the Chol group. These data suggest that rats treated with thornback ray muscle hydrolysate are less susceptible to peroxidative damage under the challenge of oxidative stress such as a high cholesterol diet. In fact the muscle hydrolysate treated by Neutrase is rich in hydrophobic peptides responsible of good antioxidant activities. ${ }^{13}$ Visioli et al. ${ }^{35}$ suggest that natural antioxidants could play a role in inhibiting the formation of cytotoxic products such as lipid peroxides thus retarding the onset of the atherosclerotic damage.

MDA level was also decreased in rats fed a cholesterolenriched diet treated with sardinelle, ${ }^{29}$ Boops boops ${ }^{12}$ and goby fish hydrolysates. ${ }^{10}$

3.7.2. Antioxidant enzyme activities in liver. GPx is an enzyme responsible for reducing $\mathrm{H}_{2} \mathrm{O}_{2}$ or organic hydroperoxides to water and alcohol, respectively. CAT catalyzes the breakdown of $\mathrm{H}_{2} \mathrm{O}_{2}$ to form water and $\mathrm{O}_{2}$. However, imbalance between the formation of reactive oxygen species and their elimination occasioned by hypercholesterolemia has been implicated in oxidative-induced diseases.

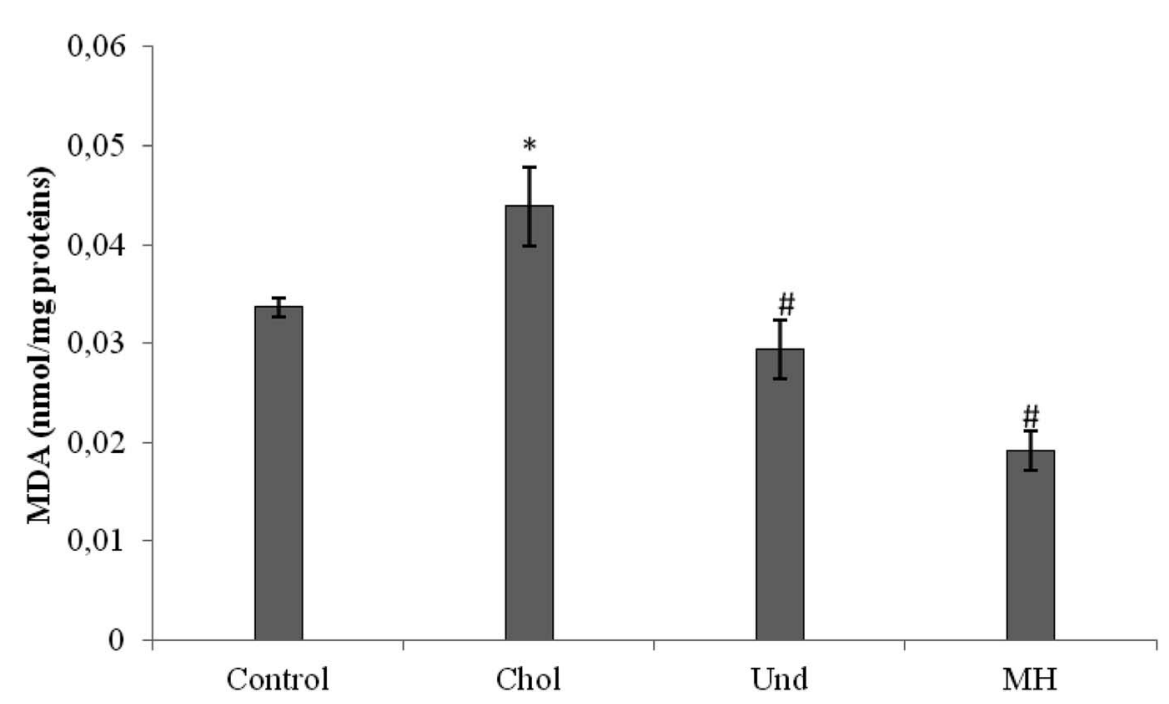

Fig. 2 Malondialdehyde (MDA) concentrations in liver of the experimental groups of rats. Control: normal rats; Chol: rats which were fed a cholesterol-rich diet for 1 month; Und: hypercholesterolemic rats given undigested muscle for 1 month; $\mathrm{MH}$ : hypercholesterolemic rats given muscle hydrolysate for 1 month. Values differ significantly at $P<0.05$. $* P<0.05$, compared with normal control rats. ${ }^{\#} P<0.05$, compared with hypercholesterolemic rats. 
The effect of administration of the muscle of thornback ray and its hydrolysate to rats fed cholesterol-enriched diet on antioxidant enzyme activities (GPx, CAT) were determined. As reported in Fig. 3, GPx (Fig. 3a) and CAT (Fig. 3b) activities in the liver of rats fed a cholesterol-enriched decreased significantly as compared to those of control group fed a normal diet. Our results are in agreement with reports of other workers which suggest that feeding a high-cholesterol diet to experimental animals depresses their antioxidant system due to increased lipid peroxidation and formation of free radicals against which the antioxidant defense has to fight, then consuming. ${ }^{36}$ The treatment of cholesterol-fed rats with muscle of thornback ray and its hydrolysate increased the CAT and GPx activities.

Our results are in agreement with that of Ben Khaled et al., ${ }^{29}$ which showed that peptides from sardinelle reduce oxidative stress in vivo and they increased the CAT and GPx activities.

\subsection{Spermogram determination}

Hypercholesterolemic diet caused a significant decrease in sperm count, mobility and viability in epididymis and testis; compared with the control group (Tables 9 and 10). Treatment with undigested muscle and especially the hydrolysate increased epididymal and testicular sperm count, mobility and viability.

Hypercholesterolemic diet caused a significant decrease in sperm count, mobility and viability in epididymis and testis; compared with the control group (Tables 9 and 10). Treatment with undigested muscle and especially the hydrolysate increased epididymal and testicular sperm count, mobility and viability, although did not counteract completely the effects of the high cholesterol diet.

The hypercholesterolemic state may result in a change in the cholesterol/phospholipid ratio of the membrane and

a)

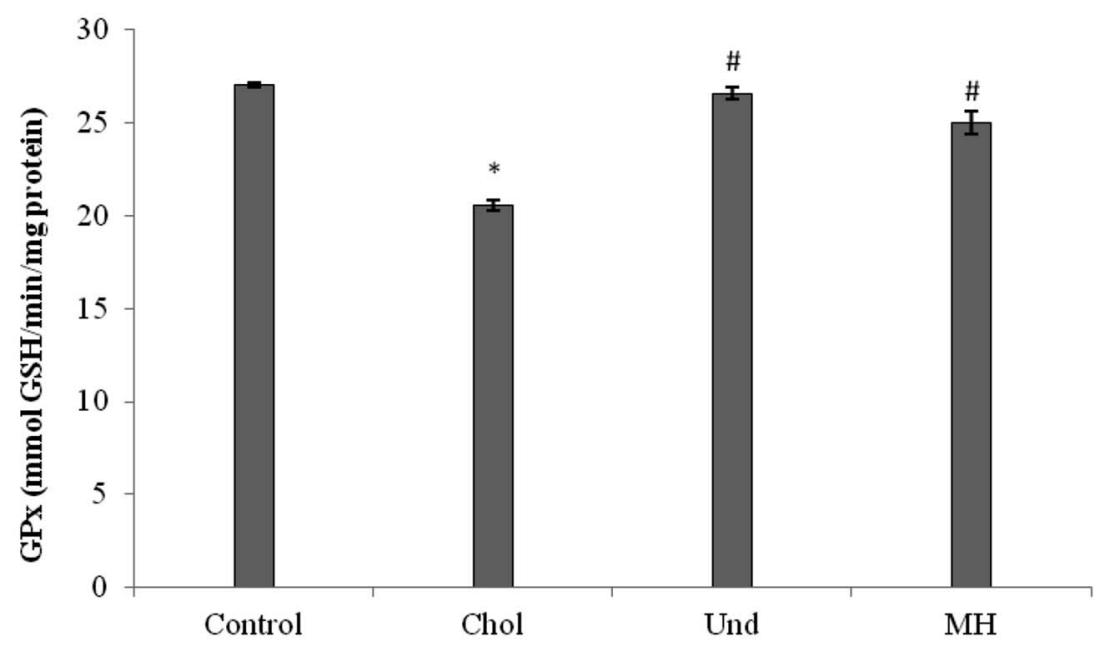

b)

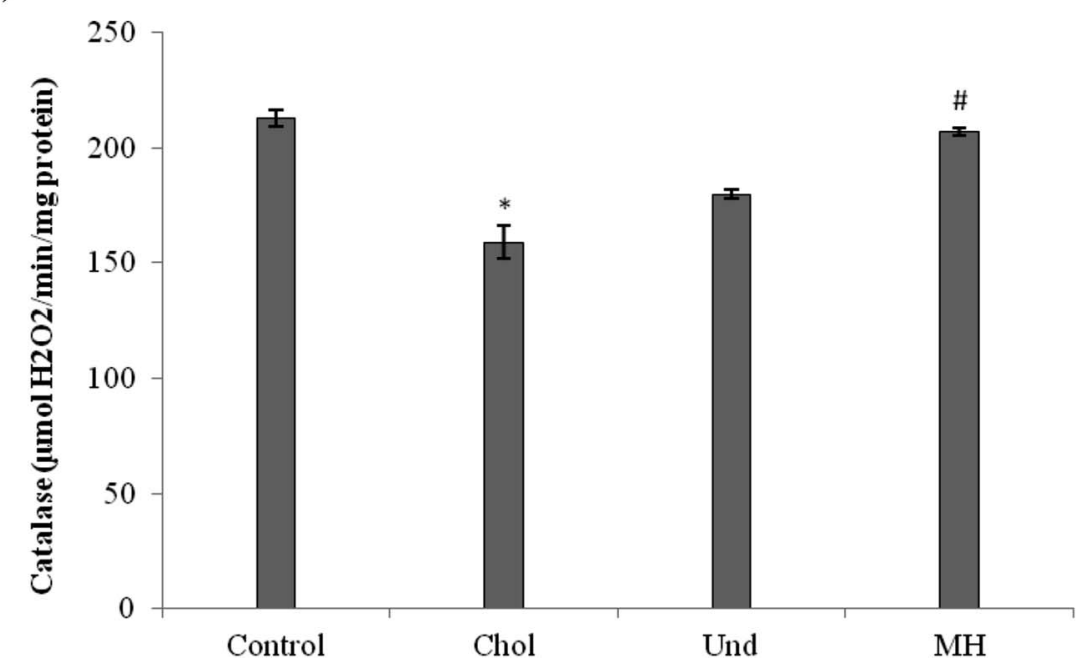

Fig. 3 Antioxidant enzyme activities (GPx and CAT) in liver of the experimental groups of rats. Control: normal rats; Chol: rats which were fed a cholesterol-rich diet for 1 month; Und: hypercholesterolemic rats given undigested muscle for 1 month; $\mathrm{MH}$ : hypercholesterolemic rats given muscle hydrolysate for 1 month. (a) Glutathione peroxidase (GPx), (b) catalase (CAT). Values differ significantly at $P<0.05 . * P<0.05$, compared with normal control rats. ${ }^{\#} P<0.05$, compared with hypercholesterolemic rats. 
Table 9 Effect of experimental diets on sperm parameters in epididymis in different rat groups ${ }^{a, b}$

\begin{tabular}{llll}
\hline Group & Motility $(\%)$ & Count $\left(10^{6} \mathrm{ml}^{-1}\right)$ & Viability (\%) \\
\hline Control & $75.00 \pm 5.00$ & $2.93 \pm 0.08$ & $60.00 \pm 10.00$ \\
Chol & $35.00 \pm 5.00^{*}$ & $2.53 \pm 0.08^{*}$ & $25.00 \pm 5.00^{*}$ \\
Und & $55.00 \pm 5.00^{* \#}$ & $2.13 \pm 0.13^{* \#}$ & $45.00 \pm 5.00^{\#}$ \\
MH & $72.00 \pm 2.50^{\#}$ & $2.78 \pm 0.03^{\#}$ & $55.00 \pm 5.00^{\#}$
\end{tabular}

${ }^{a}$ Control: normal rats; Chol: rats which were fed a cholesterol-rich diet for 1 month; Und: hypercholesterolemic rats given undigested muscle for 1 month; $\mathrm{MH}$ : hypercholesterolemic rats given muscle hydrolysate for 1 month. ${ }^{b}$ Values differ significantly at $P<0.05$. ${ }^{*} P<0.05$, compared with normal control rats. ${ }^{\#} P<0.05$, compared with hypercholesterolemic rats.

consequently a change on its dynamics which is likely to significantly affect cell function. This condition can increase membrane cholesterol which decreases the conformational freedom and biological activity of sperm surface proteins, and therefore, capacitation, or alters specific membrane proteins involved in transmembrane signaling. In addition, the deleterious effect of the hypercholesterolemic diet on the overall fertilization capacity of the spermatozoa may be at least in part attributable to the underlying oxidative stress. ${ }^{37}$ Indeed, while an optimal level of reactive oxygen species is crucial for maintaining spermatogenesis and sperm functions, an excessive production of theses oxygen species may cause oxidative stress major risk factor which affects the fertilizing potential of spermatozoa. In fact, spermatozoa are highly vulnerable to oxidative stress owing to their limited levels of antioxidant defense which strongly predispose them to lipid peroxidation. ${ }^{38}$

According to previous studies, antioxidants can help prevent and repair cell damage, so they may have an impact on the quality of sperm cells. ${ }^{39}$ On the other hand, reactive oxygen species (ROS) which result in oxidative stress are responsible for the overproduction of abnormal sperms. ${ }^{37}$ In fact, sperm are susceptible to damage from oxidative stress due to the high content of polyunsaturated fatty acids in their membranes and their limited stores of antioxidant enzymes. ${ }^{\mathbf{4 0}}$

With regard to the impact of hypercholesterolemic diet on MDA levels in hepatic tissue and the antioxidant enzyme activities in liver, the results of this study revealed that high cholesterol diet can decrease sperms' quality.

Table 10 Effect of experimental diets on sperm parameters in testis in different rat groups ${ }^{a, b}$

\begin{tabular}{llll}
\hline Group & Motility $(\%)$ & Count $\left(10^{6} \mathrm{ml}^{-1}\right)$ & Viability (\%) \\
\hline Control & $55.00 \pm 5.00$ & $1.17 \pm 0.03$ & $50.00 \pm 10.00$ \\
Chol & $17.50 \pm 2.50^{*}$ & $0.58 \pm 0.02^{*}$ & $12.50 \pm 2.50^{*}$ \\
Und & $35.00 \pm 5.00^{* \#}$ & $0.80 \pm 0.10^{*}$ & $25.00 \pm 5.00^{* \#}$ \\
MH & $45.00 \pm 5.00^{\#}$ & $1.02 \pm 0.02^{* \#}$ & $45.00 \pm 5.00^{\#}$
\end{tabular}

${ }^{a}$ Control: normal rats; Chol: rats which were fed a cholesterol-rich diet for 1 month; Und: hypercholesterolemic rats given undigested muscle for 1 month; $\mathrm{MH}$ : hypercholesterolemic rats given muscle hydrolysate for 1 month. ${ }^{b}$ Values differ significantly at $P<0.05$. ${ }^{*} P<0.05$, compared with normal control rats. ${ }^{\#} P<0.05$, compared with hypercholesterolemic rats.
Thus, antioxidant and estrogenic compounds contained in royal jelly, improve the sperm parameters in diabetic rats after oral administration. ${ }^{41}$ Also, Keskes-ammar et al. ${ }^{42}$ have reported beneficial effects of vitamin $\mathrm{E}$ and selenium supplementation on human on semen quality.

Antioxidant and/or cholesterol-lowering capacity has been proven for several dietary protein hydrolysates of various origins; but none of these hydrolysates has been studied with respect to its effect on infertility. In this first report, we show that the hydrolyzate prepared from thornback ray muscle proteins was able to prevent alteration of the fertility parameters associated with food hypercholesterolemia.

\section{Conclusion}

Based on the above results, we suggest that hypercholesterolemic diet induces a disorder in serum lipid profiles associated with an increase in the oxidative stress which most likely establishes a decrease in sperm parameters (mobility, count and viability). Undigested thornback ray muscle and especially the Neutrase hydrolysate; which exhibits a strong antioxidant activity in vitro; reduced the extent of atherosclerosis by reducing oxidative stress and serum TC, TG, LDL-C and raising serum HDL-C. They also recover spermatological damage in rats. Taking into consideration all the demonstrated manifold therapeutic potential, the results encourage further exploration of thornback ray muscle as source of bioactive peptides for functional foods or nutraceuticals.

\section{Conflicts of interest}

There are no conflicts to declare.

\section{Acknowledgements}

This work was funded by the Ministry of Higher Education and Scientific Research, Tunisia.

\section{References}

1 R. L. Yang, Y. H. Shi, G. Hao, W. Li and G. W. Le, J. Clin. Biochem. Nutr., 2008, 43, 154-158.

2 D. V. Godin and D. M. Dahlman, Res. Commun. Chem. Pathol. Pharmacol., 1993, 79, 151-166.

3 K. Prasad, S. V. Mantha, J. Kalra and P. Lee, Int. J. Angiol., 1997, 6, 13-17.

4 M. A. Shalaby, H. Y. el-Zorba and G. M. Kamel, Pharmacol. Res., 2004, 50, 137-142.

5 Z. Y. Chen, R. Jiao and K. Y. Ma, J. Agric. Food Chem., 2008, 56, 8761-8773.

6 C. C. Udenigwe and R. E. Aluko, Hypolipidemic and hypocholesterolemic food proteins and peptides, ed. Hettiarachchy, et al., Boca Raton, London, NewYork, 2012, pp. 191-218.

7 R. Nasri, I. Younes, M. Jridi, M. Trigui, A. Bougatef, N. Nedjar-Arroume, P. Dhulster, M. Nasri and M. KarraChâabouni, Food Res. Int., 2013, 54, 552-561. 
8 M. Jridi, I. Lassoued, R. Nasri, M. A. Ayadi, M. Nasri and N. Souissi, BioMed Res. Int., 2014, 461728.

9 I. Lassoued, L. Mora, A. Barkia, M. C. Aristoy, M. Nasri and F. Toldra, Int. J. Food Sci. Technol., 2016, 51, 1604-1609.

10 R. Nasri, O. Abdelhedi, I. Jemil, I. Daoued, K. Hamden, C. Kallel, A. Elfeki, M. Lamri-Senhadji, A. Boualga, M. Nasri and M. Karra-Chaabouni, Chem.-Biol. Interact., 2015, 242, 71-80.

11 M. Saito, C. Kiyose, T. Higuchi, N. Uchida and H. Suzuki, J. Agric. Food Chem., 2009, 57, 10477-10482.

12 I. Lassoued, M. Trigui, Z. Ghlissi, R. Nasri, K. Jamoussi, M. Kessis, Z. Sahnoun, T. Rebai, A. Boualga, M. LamriSenhadji, M. Nasri and A. Barkia, Food Funct., 2014, 5, 1224-1231.

13 I. Lassoued, L. Mora, R. Nasri, M. Aydi, F. Toldrá, M. C. Aristoy, A. Barkia and M. Nasri, J. Proteomics, 2015, 128, 458-468.

14 R. Agrebi, A. Haddar, N. Hmidet, K. Jellouli, L. Manni and M. Nasri, Process Biochem., 2009, 44, 1252-1259.

15 I. Lassoued, S. Hajji, S. Mhamdi, M. Jridi, A. Bayoudh, A. Barkia and M. Nasri, Int. J. Biol. Macromol., 2015, 80, 668-675.

16 E. Schnitzer, I. Pinchuk, A. Bor, M. Fainaru, I. M. Samuni and D. Lichtenberg, Chem. Phys. Lipids, 1998, 92, 151-170.

17 National Research Council, Guide for the Care and the Use of Laboratory Animals, National Institute of Health, Bethesda, 1985, 20, p. 85.

18 M. Crook, Clin. Biochem. Metabol. Med., 2006, 7, pp. 198-213.

19 W. T. Friedewald, R. T. Levy and D. S. Fredrickson, Clin. Chem., 1972, 226, 499-502.

20 K. Yagi, Biochem. Med., 1976, 15, 212-216.

21 H. Aebi, Methods Enzymol., 1984, 105, 112-126.

22 L. Flohe and W. A. Günzler, Methods Enzymol., 1984, 105, 114-121.

23 M. Ghanbari, S. B. Mortazavi, A. Khavanin and M. Khazaei, Health Scope, 2012, 1, 180-186.

24 M. Bertinaria, B. Rolando, M. Giorgis, G. Montanaro, S. Guglielmo, M. F. Buonsanti, V. Carabelli, D. Gavello, P. G. Daniele, R. Fruttero and A. Gasco, J. Med. Chem., 2011, 54, 611-621.
25 K. Srih Belguith, I. Dahech, K. Hamden, A. Feki, H. Mejdoub and H. Belghith, Int. J. Biol. Macromol., 2012, 50, 1070-1074.

26 Y. Chtourou, H. Fetoui, R. Jemai, A. Ben Slima, M. Makni and R. Gdoura, Eur. J. Pharmacol., 2015, 746, 96-105.

27 R. P. Hewawasam, K. A. P. W. Jayatilaka, C. Pathirana and L. K. B. Mudduwa, Indian J. Med. Res., 2004, 120, 30-34.

28 N. Ktari, O. Belguith-Hadriche, I. Ben Amara, A. Ben Hadj, M. Turki, F. Makni-Ayedi, T. Boudaouara, A. El Feki, A. Boualga, R. Ben Salah and M. Nasri, Food Funct., 2015, 6, 2273-2282.

29 H. Ben Khaled, Z. Ghlissi, Y. Chtourou, A. Hakim, N. Ktari, F. Makni Ayadi, A. Barkia, Z. Sahnoun and M. Nasri, Food Res. Int., 2012, 45, 60-68.

30 P. Muntner, J. Coresh, J. C. Smith, J. Eckfeldt and M. J. Klag, Kidney Int., 2000, 58, 293-301.

31 O. R. Ogunremi, A. I. Sanni and R. Agrawal, J. Funct. Foods, 2015, 17, 742-748.

32 R. Nasri, O. Abdelhedi, I. Jemil, I. Ben Amor, A. Elfeki, J. Gargouri, A. Boualga, M. Karra-Chaabouni and M. Nasri, RSC Adv., 2018, 8, 9383-9393.

33 M. Nasri, Adv. Food Nutr. Res., 2017, 81, 109-159.

34 K. Prasad and J. Kalra, Am. Heart J., 1993, 125, 958-971.

35 F. Visioli, G. Bellomo, G. F. Montedoro and C. Galli, Atherosclerosis, 1995, 117, 25-32.

36 L. Anila and N. R. Vijayalakshmi, Food Chem., 2003, 83, 569574.

37 A. Agarwal, A. Singh, A. Hamada and K. Kesari, Int Braz J Urol, 2011, 37, 432-454.

38 S. Bish, M. Faiq, M. Tolahunase and R. Dada, Nat. Rev. Urol., 2017, 14, 470-485.

39 F. H. Comhaire and A. M. Mahmoud, Reprod. BioMed. Online, 2003, 7, 385-391.

40 R. J. Aitken and M. A. Baker, Mol. Cell. Endocrinol., 2006, 250, 66-69.

41 E. Ghanbari, V. Nejati, G. Najafi, M. Khazaei and M. Babaei, Int. J. Fertil. Steril., 2015, 9, 113-120.

42 L. Keskes-ammar, N. Feki-chakroun, T. Rebai, Z. Sahnoun, H. Ghozzi, S. Hammami, K. Zghal, H. Fki, J. Damak and A. Bahloul, Arch. Androl., 2003, 49, 83-94. 